\title{
Examining the Predictive Role of Scientific Creativity on Preservice Science Teachers' Academic Motivation
}

\author{
Ebru Bakaç \\ Department of Educational Sciences, Faculty of Education, Sinop University, Turkey
}

Copyright $\mathrm{O} 2018$ by authors, all rights reserved. Authors agree that this article remains permanently open access under the terms of the Creative Commons Attribution License 4.0 International License

\begin{abstract}
The purpose of this research is to examine preservice science teachers' development of academic motivation and scientific creativity. It also investigated the predictive role of academic motivation on preservice science teachers' scientific creativity. The study group of the research consisted of $(\mathrm{N}=140)$ preservice science teachers who are studying at the Faculty of Education located in Northwest Black Sea Region of Turkey during the fall semester of the 2016-2017 academic year. Data were collected through "Academic Motivation Scale" developed by Vallerand, Pelletier, Blais, Brière, Senécal and Vallières (1992) and adapted into Turkish by Unal Karaguven (2012) [49] and "Scientific Creativity Scale " developed by $\mathrm{Hu}$ and Adey (2002) and adapted to Turkish by Denis Celiker (2012) [16]. At the end of the research, it was found that internal motivation for success and age was an important predictor of preservice teachers' scientific creativity levels.
\end{abstract}

Keywords Creativity, Scientific Creativity, Motivation, Academic Motivation

\section{Introduction}

In recent years, there has been a growing interest by the researchers to concept of creativity. As a result of his/her literature review, Welsch (1973) [51] identified that the creativity was tried to explained by various ways by the researchers but there was not a certain definition of creativity in the literature. For example, Torrance (1990) [48] tried to describe the creativity with the concepts of rationality, resilience and original thinking. Otherwise, Lubart (1994) [34] suggested that the problem-solving process triggered the creativity and that if there was a problem, a creative solution would come along with it. The childhood was regarded as a starting point for creative thinking but it can say that conscious creative activities begin to form during the age of adolescence. Afterwards, creativity manifests itself through scientific inventions, discoveries and artistic designs in adulthood
(Starko, 2005) [47]. If the scientific creativity which is tried to defined based on the concept of creativity, it was expressed that adding new information to the scientific knowledge, making new experiments in order to explore the laws of nature deeply, building new theories and developing new ideas for the application (Moravcsik, 1981) [36]. Beside according to $\mathrm{Hu}$ and Adey (2002) [29], the scientific creativity is a process which comprising finding and solving creative scientific problems. It was considered as a kind of ability comprising such mental factors. It was thought that the scientific creativity emerged from the scientific processing skills and the scientific knowledge. Some scientists explained the concept of creativity in association with scientific processes and problem-solving. For instance, Mumford, Reiter-Palmon and Redmond (1994) [37] pointed out that the problem-solving as a form of the creative thinking. Also, Kozbelt, Beghetto and Runco (2010) [32] suggested that more creative outcomes could produce with not well-defined problems. The creative problem-solving model (CPS) developed by Osborn-Parnes does not only explains the creative process but also attempts to explain how individuals can use the creativity in different circumstances. According to the model, every process comes from several steps comprising divergent and convergent thinking. The processes are listed as finding a complex situation, finding data, finding an idea, finding a solution, and acceptance process in the model (Starko, 2005) [47]. Other hand, problem-finding theories were emerged as a reaction to the problem-solving theories that occurred with a conventional understanding in a creative process and the first step of the theories is the configuration of the problem as one of the cognitive processes that play an important role in the creative thought (Mumford, Reiter-Palmon and Redmond, 1994). Problem-finding and formulating of hypotheses include among the steps of scientific process skills. Because of this, it was accepted that the individuals who are able to use the scientific process skills better, they have more scientific creativity (Hu and Adey, 2002) [29].

Creating a product includes a long process in most of the cases. Hence, motivation plays an important role in the 
creative thinking process. The concept of motivation was found itself a place in different disciplines with the purpose of explaining what human behavior is and why it is realized (Deci and Ryan, 2000) [14]. For it is a much-studied concept, many definitions of the motivation made by the researchers. According to Eggen and Kauchak (1994) [20], motivation defined as a power that guides and actualizes a behavior which was performed toward a goal. Pintrich and Schunk (2002) [40] pointed out that motivation as a process by which an activity was started and continued directly toward a goal. Motivation is a state which is covers all factors that determine the degree of willingness to initialize an activity or the creation of such a state (Evans, 2000) [20]. Consequently, it can be said that such a state is a factor which supports the manifestation of the creativity.

Literature findings show that there is a positive correlation between motivation, self-confidence over ability and use of strategy (Pintrich and De Groot, 1990; Zimmerman and Martinez-Pons, 1990) [39] [55]. According to Pintrich and Schunk (2002) [40], individuals are motivated to engage in physical and cognitive activities at all times in order to achieve what they have in their mind. Similarly, Moneta and Siu (2002) [35] state that persons with high motivation exhibit a higher degree of creativity. Beside according to Abuhamdeh and Csikzentmihalyi (2002) [1], individuals might change their personality characteristics and motivation by using the knowledge in any field of specialty. If an individual makes an innovation in his own field of specialty and an innovation is given value by society, it is considered that he/she is a creative individual (Kaufman, 2009) [31]. Similarly, Amabile's (1996; 1998: 78) [5] [6] Componential Creativity Model consists of three parts as field-related skills (specialty), general skills related with creativity (appropriate cognitive styles) and task motivation. According to the componential creativity model, the first component is the skills related to the field, in other word, the specialty. Specialty has a vital importance for all creative works. For example, a bioengineer uses their biochemistry knowledge, genetic knowledge, acquired lab skills and outcomes of similar studies made in the field in order to solve any complex problems related with their own field (Amabile, 1996) [5]. Skills related to creativity, the second component, are such skills as looking at a problem from a different perspective, applying different techniques to discover new cognitive ways, etc. Amabile, Conti, Coon, Lazenby and Herron (1996) [8] state that personal skills such as showing tolerance to uncertainties, propensity to risk-taking, self-discipline, perseverance and indifference to social affirmation support the creative thinking process. Even if individuals are a very good specialists in their own field whether their creativity skills are not an adequate level, they will not create any creative products.

Task motivation, the third component, defines what the individual can do. According to Amabile (1985) [4], motivational synergy is one of the social factors that affects the creativity. Exhibiting socially accordance toward a task is the most important variable coming after the task itself. In this case, individuals who approach their task with intrinsic motivation are generally more creative than those who approach it with extrinsic motivation.

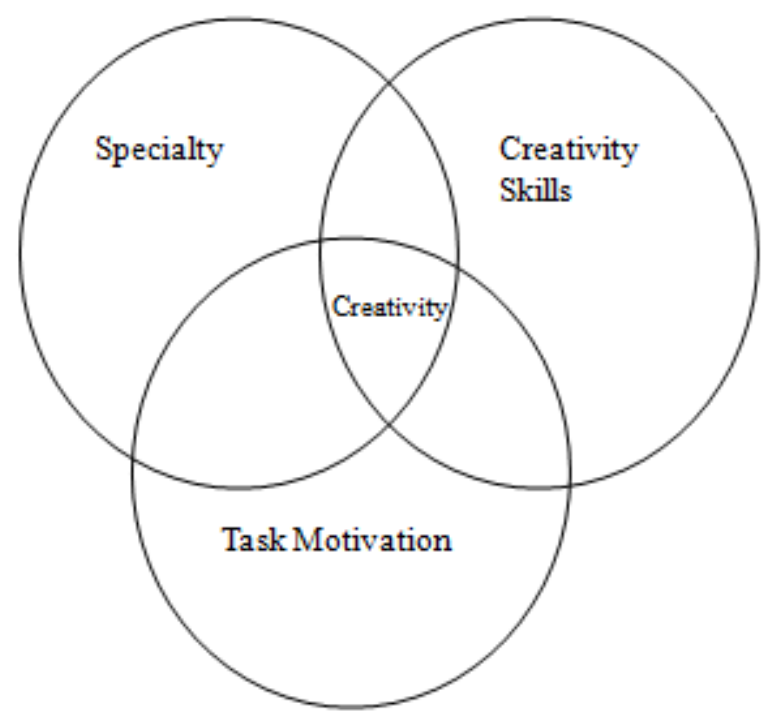

Figure 1. Amabile's (1996) componential creativity model

Various theories suggested for the better understanding of the concept of motivation. One of these theories is the Self-Determination Theory developed by Deci \& Ryan (2000) [14]. According to this theory, different motivation types leads to different behaviors. Individuals can exhibit behaviors on intrinsic motivation, extrinsic motivation or amotivation (Deci \& Ryan, 2000) [14]. Intrinsic motivation, which is non-impulsive motivation, denotes that energy is intrinsic in the nature of an organism (Deci \& Ryan, 1985) [12 ] and the organization exhibits a behavior because it is interesting or enjoyable (Deci, Koestner \& Ryan, 2001; Ryan \& Deci, 2000) [15] [43], while extrinsic motivation denotes an expectation of an outcome which is distinct from the exhibited behavior (Deci \& Ryan, 2000; Ryan, \& Deci, 2000) [14] [43]. Finally, amotivation occurs when an activity has become meaningless (Ryan, 1995) [42]. While motivation means taking action in order to realize a behavior, amotivation is expressed as a state of lack of intention to take action (Ryan \& Deci, 2000) [43].

It is seen that the Self-Determination Theory is also reflected the field of education through various studies (Deci \& Ryan, 1985; Deci, Vallerand, Pelletier \& Ryan, 1991) [12] [13]. It was named academic motivation in the education field. The academic motivation defined by starting from the concept of motivation was explained as the willingness the students have in order to attain certain academic goals (Wilkesmann, Fischer and Virgilito, 2012: 4) [52]. Bozanoglu (2004) [10] pointed out that academic motivation is the generation of the energy needed for any academic tasks. Also, Schunk (1991) [46] explained the academic motivation by associating with the concept of 
self-competence. Finally, Fidan (1986) [23] stated that academic motivation is one of the factors that determine the direction and the determination of the student behavior. The concept of motivation asks the question of "Why do we perform the behavior?" while the academic motivation looks for an answer to the question of "What is our purpose for attending school?" (Vallerand, Pelletier, Blais, Briere, Senecal \& Vallieres, 1992) [50]. The concept of academic motivation expressed by Vallerand et al. (1992) [50] as follows: The intrinsic motivation consists of three sub-dimensions as intrinsic motivation to know, accomplish things and experience stimulation. The extrinsic motivation consists of three sub-dimensions as identified extrinsic motivation, introjected external motivation and external regulation. The last component of the theory was named amotivation by using the components contained in the Self-Determination Theory (as in the measurement tool used in this study).

Although such studies were found to mention the relationship between motivation and creativity (Conti, Collins and Picariello, 2001; Hennessey and Amabile, 1998; Selart, Nordström, Kuvaas and Takemura, 2008; Zhang and Bartol, 2010), [11] [28] [45 ] [54] the relationship between the academic motivation and various variables (Duchesne \& Larose, 2007; Durmaz ve Akkus, 2016; Fortier, Vallerand \& Guay, 1995; Yerdelen, Aydın, Yalmanc1 \& Goksu, 2014) [17] [18] [24 ] [53], the relationships between the scientific creativity and various variables (Aktamıs \& Ergin, 2007; Huang, Peng, Chen, Tseng \& Hsu, 2017; Pekmez, Aktamıs \& Can, 2010) [2] [27] [38] as a result of a literature review made by the researcher within the scope of this study, no study that explains the relationship between the academic motivation and the scientific creativity was found in the literature. In this context, it was expected to make a significant contribution to the field in terms that examines the development of the scientific creativity and academic motivation levels of preservice science teachers. Also, it was examined the relationship between these two variables. It is thought that development of the academic motivation will positively affect the education life of the preservice science teachers and ensure the development of the task and responsibility consciousness. Beside it is thought that any activities performed for development of preservice science teachers' scientific creativity will affect their creative potential significantly because it can be said that the preservice science teachers who were graduated with a developed creativity skill will carry on a more successful professional life, guide their students better and produce more practical solutions to any problems encountered by them in different circumstances.

The purpose of this research is to examine preservice science teachers' development of academic motivation and scientific creativity. It also investigated the predictive role of academic motivation on preservice science teachers' scientific creativity. Based on the relationships presented in the literature, this study poses the following hypotheses:

1) Accepting develop of preservice science teachers' scientific creativity at the end of the university education.

2) Accepting develop of preservice science teachers' academic motivation at the end of the university education.

3) Accepting academic motivation of preservice science teachers has a predictive role their level of scientific creativity.

\section{Materials and Methods}

\subsection{The Research Model}

In the scope of this research, descriptive model were used. The existence of any covariance between two or more variables was tried to identify (Karasar, 2015) [30]. In this research, the development level of preservice science teachers' academic motivation and scientific creativity was examined. In addition, it was researched the power of academic motivation to predict the level of scientific creativity

\subsection{Participants}

The participants of the research consisted of $(\mathrm{N}=140)$ preservice science teachers who are studying at the Faculty of Education located in Northwest Black Sea Region of Turkey during the fall semester of the 2016-2017 academic year. These participants of $72.9 \%$ were female $(n=102)$ and $27.1 \%$ were male $(n=38)$. The reason for the inclusion of these students in the study group can be explained that preservice science teachers are taking part in the frequency of scientific activities is greater among the students who are studying in the Science Education program than the other departments.

\subsection{Data Gathering Tools}

\subsubsection{Academic Motivation Scale}

"Academic Motivation Scale" was used to determine the academic motivation of preservice science teachers that was developed by Vallerand, Pelletier, Blais, Brière, Senécal and Vallières (1992) and adapted to Turkish by Unal Karaguven (2012) [49]. The validation and confidence studies were performed on total 390 university students of "Academic Motivation Scale" and which was concluded in 28 items consists of seven sub-dimensions as intrinsic motivation to know, accomplish things and experience stimulation, identified extrinsic motivation, introjected extrinsic motivation, extrinsic motivation (extrinsic regulation) and amotivation. The Cronbach alpha value for the scale was found .87 . It was determined that 
the item-total correlations of the items contained in the scale varied between .22 and .64 (Unal Karaguven, 2012) [49]. The Cronbach alpha value for the scale was found .80 in this study.

\subsubsection{Scientific Creativity Scale}

"Scientific Creativity Scale" developed by $\mathrm{Hu}$ and Adey (2002) and adapted to Turkish by Denis Celiker (2012) [16] was used to determine preservice science teachers' creative thinking skills. The scale was applied to 389 students and it was obtained final form which consisting of seven items and single dimension. The Cronbach alpha internal consistency coefficient value was found .86. The item-total correlations of the items contained were determined to vary between .37 and .74 in the scale (Deniş Celiker, 2012) [16]. The Cronbach alpha value was calculated .62. in this study

\subsection{Data Analysis}

The scales were applied to preservice science teachers $(\mathrm{N}=140)$ who are studying at Faculty of Education located in Northwest Black Sea Region of Turkey during the fall semester of the 2016-2017 academic year. The SPSS 22 package program was used for analysis of the quantitative data which obtained from the research. Descriptive statistics were used to determine preservice science teachers' scientific creativity level and academic motivation level and regression analysis were used to determine if academic motivation of preservice science teachers' predict their level of scientific creativity

\section{Results}

The findings related with the variables are presented in Table 1, Table 2 and Table 3.

When Table 1 is examined, it is seen that the arithmetic mean of the scientific creativity score of the $1^{\text {st }}$ grade preservice science teachers are $(\overline{\mathrm{X}}=42.46 \mathrm{SS}=16.82), 2^{\text {nd }}$ grade preservice science teachers are $(\overline{\mathrm{X}}=43.33 \mathrm{SS}=17.36)$, $3^{\text {rd }}$ grade preservice science teachers are $(\overline{\mathrm{X}}=52.30$ $\mathrm{SS}=18.82)$ and finally, $4^{\text {th }}$ grade preservice science teachers are $(\bar{X}=60.07 \mathrm{SS}=16.43)$. This finding can be interpreted such as a development occurred in the scientific creativity skills of preservice science teachers as a result of the teacher training education they received for four years.

Table 1. Results of Preservice Science Teachers' Scientific Creativity

\begin{tabular}{cccccc}
\hline Scientific Creativity Scale & $\mathrm{N}$ & Min & Max & $\overline{\mathrm{X}}$ & $\mathrm{Ss}$ \\
\hline $1^{\text {st }}$ grade & 41 & 4.00 & 77.00 & 42.46 & 16.82 \\
$2^{\text {nd }}$ grade & 39 & 15.00 & 86.00 & 43.33 & 17.36 \\
$3^{\text {rd }}$ grade & 33 & 19.00 & 89.00 & 52.30 & 18.82 \\
$4^{\text {th }}$ grade & 27 & 29.00 & 101.00 & 60.07 & 16.43 \\
\hline
\end{tabular}

Table 2. Results of Preservice Science Teachers' Academic Motivation

\begin{tabular}{cccccc}
\hline Academic Motivation Scale & $\mathrm{N}$ & Min & Max & $\overline{\mathrm{x}}$ & $\mathrm{Ss}$ \\
\hline $1^{\text {st }}$ grade & 36 & 73.00 & 158.00 & 122.66 & 23.20 \\
$2^{\text {nd }}$ grade & 37 & 83.00 & 157.00 & 121.94 & 19.13 \\
$3^{\text {rd }}$ grade & 33 & 86.00 & 167.00 & 132.12 & 19.95 \\
$4^{\text {th }}$ grade & 27 & 89.00 & 166.00 & 130.40 & 15.87 \\
\hline
\end{tabular}

When Table 2 is examined, it is seen that the arithmetic mean of the academic motivation scores of the $1^{\text {st }}$ grade preservice science teachers are $(\overline{\mathrm{X}}=122.66 \mathrm{SS}=23.20), 2^{\text {nd }}$ grade preservice science teachers are $(\overline{\mathrm{X}}=121.94$ $\mathrm{SS}=19.33), 3^{\text {rd }}$ grade preservice science teachers are $(\bar{X}=132.12 \mathrm{SS}=19.95)$ and finally $4^{\text {th }}$ grade preservice science teachers are $(\bar{X}=130.40 \mathrm{SS}=15.87)$. This finding can be interpreted as academic motivation of preservice science teachers did not change much at the beginning of their university study, only their academic motivation raised slightly at the $3^{\text {rd }}$ grade which they were taken more teacher education courses and their academic motivation decreased a little in the final grade because the amount of teacher education courses were decreased.

Table 3. Results of the Multiple Regression Analysis

\begin{tabular}{ccccccccc}
\hline Variables & $\mathrm{B}$ & Standard Error & $\beta$ & $\mathrm{t}$ & $\mathrm{p}$ & Zero-order r & Partial $\mathrm{r}$ \\
\hline Constant & 27.453 & 11.638 & - & 2.359 & .020 & & \\
Intrinsic Motivation to Know & -.516 & .503 & -.140 & -1.024 & .308 & .060 & -.092 \\
Intrinsic Motivation to Accomplish Things & 1.230 & .496 & .340 & 2.482 & .014 & .116 & .218 \\
Intrinsic Motivation to Experience Stimulation & -.078 & .431 & -.023 & -.182 & .856 & .066 & -.016 \\
Identified Extrinsic Motivation & .238 & .356 & .064 & .667 & .506 & .018 & .060 \\
Introjected Extrinsic Motivation & -.793 & .342 & -.239 & -2.316 & .022 & -.062 & -.204 \\
Extrinsic Regulation & .187 & .370 & .046 & .507 & .613 & .044 & .045 \\
Amotivation & .422 & .270 & .147 & 1.562 & .121 & .055 & .139 \\
Age & 4.135 & 1.051 & .337 & 3.934 & .000 & .314 & .333 \\
\hline
\end{tabular}

$\mathrm{R}=0.402 \mathrm{R}^{2}=0.161 \mathrm{~F}_{(8,124)}=2.981 \mathrm{p}=0.004$ 
When Table 3 is examined, it is seen that there is a positive and moderate correlation $(\mathrm{r}=0.31)$ between age and scientific creativity level of preservice science teachers. When the other variables are keep constant, there is a significant correlation $(\mathrm{r}=0.33)$ between the two variables. Similarly, it is seen that there is a positive and low correlation $(\mathrm{r}=0.12)$ between the intrinsic motivation to know and scientific creativity level of preservice science teachers. When the other variables are keep constant, it is seen that there is a positive and low correlation $(\mathrm{r}=0.12)$ between the intrinsic motivation to accomplish things and scientific creativity level of preservice science teachers. When the other variables are keep constant, it is seen that there is a positive and low correlation $(\mathrm{r}=0.22)$ between the two variables.

The age and academic motivation of preservice science teachers give a low correlation with their scientific creativity $\left(\mathrm{R}=0.402, \mathrm{R}^{2}=0.161 ; \mathrm{p}<0.01\right)$. Consequently, the two variables explain approximately $16 \%$ of the scientific creativity of preservice science teachers. According to the standardized regression coefficient $(\beta)$, the order of importance of the predictive variables is the intrinsic motivation to accomplish things and the age. In the examination of the results of t-test related with the significance of the regression coefficients, it is seen that the age and the intrinsic motivation to accomplish things are an important predictor on the level of scientific creativity of the teacher candidates.

\section{Discussion}

The purpose of this research is to examine preservice science teachers' development of academic motivation and scientific creativity. It also investigated the predictive role of academic motivation on preservice science teachers' scientific creativity. As a result of the analyses, it was concluded that age and intrinsic motivation to accomplish things are an important predictor on the scientific creativity level of preservice science teachers. It was also seen that when the grade level of preservice science teachers' rose, the scientific creativity of them were improved. Finally, it was determined that academic motivation of preservice science teachers' followed a fluctuating path.

At the end of the research, it was determined that age was an important predictor of scientific creativity level of preservice science teachers. It is seen that findings similar to this findings presented by (Binnewies, Ohly \& Niessen, 2008) [9] in the literature. Binnewies, Ohly \& Niessen (2008) [9] was noted that there is a positive correlation between age and creativity under a high supervision focus in a study conducted on nurses. It was determined that younger employees are more creative under low supervision focus and older employees are more creative under high supervision focus. When considering the age range of preservice science teachers, it can be said that such findings supporting the study found in this research as well. On the other hand, Eder \& Sawyer (2007) [19] found that there is not any correlation between the age and general creativity in a meta-analysis study. However, Eder \& Sawyer (2007) [19] suggested that there are many intermediary variables that affect the relationship between the age and creativity and these should be researched diligently.

At the end of the research, it was determined that intrinsic motivation is an important predictor of scientific creativity. Similarly, Oral, Kaufman \& Agars (2007) [41] were shown that the intrinsic motivation is an important predictor of general creativity and high-level intrinsic motivation leads to high-level creativity in the regression model set up in two studies. There are also studies in the literature which show that there is a correlation between the intrinsic motivation and high-level creativity (Amabile, 1985; Amabile, Hennessey \& Grossman, 1986; Ruscio, Whitney \& Amabile, 1998) [4] [7] [44]. Also, Emir, Erdogan \& Kuyumcu (2007) [21] pointed out that the educational background of the mother and the academic accomplishments in Turkish teaching of the students are an important predictor of their general creativity.

When the grade of preservice science teachers' rises, a development occur their scientific creativity as well as other research results. Also, Oral, Kaufman \& Agars (2007) [41] state that creativity tends to improve by age which seems to support the finding in this research. Similarly, in a research that included total 1085 preschool, elementary, secondary and high school students, approximately one hundred students from each grade, were examined according to their total creativity scores from all grades by Koksal Akyol \& Salı (2016) [33]. At the end of the research, it was found that the scores of the students who are studying grades one, two and three generally lower than the scores of the students who are studying grades five and above. At lastly, it was determined that the creativity scores rise after the grade three. Beside, in a study conducted by Alacapınar (2013) [3] it was examined the development of creativity level of the elementary school students who are studying from grade $3^{\text {rd }}$ to $8^{\text {th }}$ and it was found that improve the elementary school students' creativity level from grade $3^{\text {rd }}$ to $8^{\text {th }}$.

Finally, it was determined that preservice science teachers' academic motivation levels show a different according to their grade. When the literature reviewed by the researcher it reveals partly similar results by (Eymur Geban, 2011; Gomleksiz and Serhatloglu, 2013) [25] [26]. Eymur Geban (2011) [25] determined that academic motivation level of the chemistry teacher candidates who are studying at first grade is higher than the other grades. Also, this study reveals that the academic motivation of the first-grade students have higher academic motivation level than the second-grade students. Finally, Gomleksiz and Serhatloglu (2013) [26] found that academic motivation 
level of the teacher candidates who are studying at first grade is higher than the final grade. It was explained by the fact that the teachers candidates who are studying at first grade have recently started the university education and it can say that they are more excited and willing to school. This result suggests that the curriculums should be arranged in a manner to raise the academic motivation in the Education Faculties.

\section{Conclusions}

It was seen that preservice science teachers' scientific creativity skills improved as a result of the education which they received at the university. According to this finding, it would be convenient to examine scientific creativity level of preservice teachers who are studying in other departments or the students who are studying in different faculties. It was found that no change occurred in preservice science teachers' academic motivation level at the beginning of their university education and their academic motivation improved at third grade where they took more education courses and lastly their academic motivation level decreased slightly at the final grade. Based on this finding, qualitative studies could design to identify the factors which affect academic motivation of preservice science teachers. It was found that age and intrinsic motivation to accomplish things is an important predictor of scientific creativity level of preservice science teachers and it recommended that the activities which improve the teacher candidates' intrinsic motivation could be incorporated into the university courses.

\section{Acknowledgements}

The author (s) would like to thank the students who helped with data collection.

\section{REFERENCES}

[1] Abuhamdeh, S., \& Csikszentmihalyi, M. (2002). The artistic personality: A systems perspective. In R. J. Sternberg, E. L. \& Grigorenco \& J. L. Singer (Eds.), Creativity: From potential to realization (pp. 31 - 42). Washington, DC: American Psychological Association.

[2] Aktamis, H. \& Ergin, O. (2007). Investigating the relationship between science process skills and scientific creativity. H. U. Journal of Education, 33, 11-23.

[3] Alacapınar, F. G. (2013). Grade level and creativity. Eurasian Journal of Educational Research, 50, 247-266.

[4] Amabile, T. M. (1985). Motivation and creativity: Effects of motivational orientation in creative writers. Journal of Personality and Social Psychology, 48, 393-397.
[5] Amabile, T. M. (1996). Creativity in context: Update to the social psychology of creativity. Westview Press.

[6] Amabile, T. M. (1998). How to kill creativity. Boston, MA: Harvard Business School Publishing.

[7] Amabile, T. M., Hennessey, B. A. \& Grossman, B. S. (1986). Social influences on creativity: The effects of contracted - for reward. Journal of Personality and Social Psychology, 50, 14-23.

[8] Amabile, T. M., Conti, R., Coon, H., Lazenby, J., \& Herron, M. (1996). Assessing the work environment for creativity. Academy of management journal, 39(5), 1154-1184.

[9] Binnewies, C., Ohly, S. \& Niessen, C. (2008). Age and creativity at work: The interplay between job resources, age and idea creativity. Journal of Managerial Psychology, 23 (4), 438-457. https://doi.org/10.1108/02683940810869042.

[10] Bozanoglu, I. (2004). Academic motivation scale: development, reliability, validity. Ankara University Journal of Faculty of Educational Sciences, 2, 83-98.

[11] Conti, R., Collins, M. E. \& Picariello, M. L. (2001).The impact of competition on intrinsic motivation and creativity: Considering gender, gender segregation and gender role orientation. Personality and Individual Differences, 30, 1273-1289.

[12] Deci, E. L., \& Ryan, R. M. (1985). Intrinsic motivation and self-determination in human behavior. New York: Plenum.

[13] Deci, E.L., Vallerand, R.J., Pelletier, L.G. \& Ryan, R.M. (1991). Motivation and education: The self-determination perspective. The Educational Psychologist, 26, 325-346.

[14] Deci, E. L. \& Ryan, R. M. (2000). The "what" and "why" of goal pursuits: human needs and the self-determination of behavior. Psychological Inquiry, 11(4), 227 - 268.

[15] Deci, E. L., Koestner, R., \& Ryan, R. M. (2001). Extrinsic rewards and intrinsic motivation in education: Reconsidered once again. Review of Educational Research. 71, 1-27.

[16] Deniş Celiker, H. (2012). Science and technology course in the unit of 'solar system and beyond: Space puzzle' the effect of project-based learning applications on student achievements, creative thinking and their attitudes towards science and technology. (Unpublished doctoral dissertation). Dokuz Eylul University, Institute of Educational Sciences, Izmir.

[17] Duchesne, S., \& Larose, S. (2007). Adolescent parental attachment and academic motivation and performance in early adolescence. Journal of Applied Social Psychology, 37(7), 1501-1521.

[18] Durmaz, M. \& Akkus, R. (2016). Mathematics anxiety, motivation and the basic psychological needs from the perspective of self-determination theory. Education and Science, 41(183), 111-127.

[19] Eder, P. \& Sawyer, J.E. (2007), “A meta-analytic examination of employee creativity", paper presented at the 22nd Annual Conference, Society of Industrial and Organizational Psychology (SIOP), New York, NY, April.

[20] Eggen, P. \& Kauchak, D. (1994). Educational Psychology: Classroom connections. New York: Macmillan College 
Publishing Company.

[21] Emir, S., Erdogan, T. \& Kuyumcu, A. (2007). Turkçe ogretmenligi ogrencilerinin yaratıcı duşunme duzeyleri ile sosyo-kulturel ozelliklerinin ilişkisi. Hasan Ali Yucel Egitim Fakultesi Dergisi, 4(1), 73-87.

[22] Evans, L. (2000). The effects of educational change on morale, job satisfaction and motivation. Journal of Educational Change, 1, 173-192.

[23] Fidan. N. (1986). Okullarda ogrenme ve ogretme. Ankara: Yelkentepe Press.

[24] Fortier, M. S., Vallerand, R. J., \& Guay, F. (1995). Academic motivation and school performance: Toward a structural model. Contemporary educational psychology, 20(3), 257-274

[25] Eymur, G. \& Geban, Ö. (2011). An investigation of relationship between motivation and academic achievement of pre-service chemistry teachers. Education and Science, $36,246-255$.

[26] Gomleksiz, M. N. \& Serhatloglu, B. (2013). Prospective teachers' perceptions of academic motivation levels. Turkiye Sosyal Arastırmalar Dergisi, 17(3), 99-127.

[27] Huang, P. S., Peng, S. L., Chen, H. C., Tseng, L. C., \& Hsu, L. C. (2017). The relative influence of domain knowledge and domain-general divergent thinking on scientific creativity and mathematical creativity. Thinking Skills and Creativity, 25, 1-9.

[28] Hennessey, B. A. \& Amabile, T. Y. M. (1998). Reward, intrinsic motivation and creativity. American Psychologist, $53,674-675$.

[29] Hu, W. \& Adey, P. A (2002). Scientific creativity test for secondary school students. International Journal of Science Education, 24(4), 389 - 403.

[30] Karasar, N. (2015). Bilimsel arastırma yontemi. Ankara: Nobel Press.

[31] Kaufman, J. C. (2009). Creativity 101. Newyork, NY: Springer Publications.

[32] Kozbelt, A., Beghetto, R. A., \& Runco, M. A. (2010). Theories of creativity. In J. C. Kaufman \& R. J. Sternberg (Eds.), Cambridge handbook of creativity. (pp. 20-47). New York NY: Cambridge University Press.

[33] Koksal Akyol, A. \& Sal1, G. (2016). An investigation of creativity among children in kindergartens, primary, middle and high schools. Journal of Theoretical Educational Science, 9(3), 379-399.

[34] Lubart, T. I. (1994). Creativity. In R. J. Sternberg (eds.). Thinking and problem-solving. (pp. 290-332). San Diego, CA: Academic.

[35] Moneta, G. B. \& Siu, C. M. (2002). Trait intrinsic and extrinsic motivations, academic performance, and creativity in Hong Kong college students. Journal of College Student Development, 43(5), 664-83.

[36] Moravcsik, M. J. (1981). Creativity in science education. Science Education, 65(2), 221 - 227.

[37] Mumford, M. D., Reiter-Palmon, R., \& Redmood, M.
(1994). Problem instruction and cognition: Applying problem representations in ill-defined domains. In $\mathrm{M}$. Runco (ed.), Problem finding, problem-solving, and creativity (pp. 3-39). Norwood, NJ: Ablex.

[38] Pekmez, E. S., Aktamış, H., \& Can, B. (2010). The effectiveness of science laboratory course regarding the scientific process skills and scientific creativity of prospective teachers. Inonu University Journal of the Faculty of Education, 11(1), 93-112.

[39] Pintrich, P. R., \& De Groot, E. V. (1990). Motivational and self-regulated learning components of classroom academic performance. Journal of Educational Psychology, 82, 33-40.

[40] Pintrich, P. R., \& Schunk, D. H. (2002). Motivation in education: Theory, research, and applications. (2. ed.). New Jersey: Prentice Hall.

[41] Oral, G., Kaufman, J. C. \& Agars, M. D. (2007). Examining creativity in Turkey: do Western findings apply?. Journal High Ability Studies, 18(2), 235-246.

[42] Ryan, R. M. (1995). Psychological needs and the facilitation of integrative processes. Journal of Personality, $63,397-427$.

[43] Ryan, R. M., \& Deci, E. L. (2000). Intrinsic and extrinsic motivations: classic definitions and new directions. Contemporary Educational Psychology, 25, 54-67.

[44] Ruscio, J., Whitney, D. M. \& Amabile, T. M. (1998). Looking inside the fishbowl of creativity: Verbal and behavioral predictors of creative performance. Creativity Research Journal, 11, 243-263.

[45] Selart, M., Nordström, T., Kuvaas, B. \& Takemura, K (2008). Effects of reward on self - regulation, intrinsic motivation and creativity. Scandinavian Journal of Educational Research, 52(5), 439-458.

[46] Schunk, D. H. (1991). Self-efficacy and academic motivation. Educational Psychologist, 26(3-4), 207-231.

[47] Starko, A. (2005). Creativity in the classroom: Schools of curious delight. (3th ed.). Mahwah, NJ: Lawrence Erlbaum Associates.

[48] Torrance, E. P. (1990). The Torrance tests of creative thinking norms technical manual figural (streamlined) forms A \& B. Bensenville, IL: Scholastic Testing Service Inc.

[49] Unal Karagüven, H. (2012). The adaptation of academic motivation scale to turkish. Educational Sciences: Theory \& Practice. 12(4), 2599-2620.

[50] Vallerand, R. J., Pelletier, L. G., Blais, M. R, Brière, N. M., Senécal, C., \& Vallières, E. F. (1992). The academic motivation scale: a measure of intrinsic, extrinsic, and amotivation in education. Educational and Psychological Measurement, 52, 1003-1017.

[51] Welsch, G. S. (1973). Perspectives in the study of creativity. Journal of Creative Behavior, 7, 231-246.

[52] Wilkesmann, U., Fischer, H., \& Virgillito, A. (2012). Academic Motivation of Students -the German Case. Zentrum für Weiterbildung. 
[53] Yerdelen, S., Aydın, S., Yalmancı, S. G. \& Göksu, V. (2014). Relationship between high school students achievement goal orientation and academic motivation for learning biology: a path analysis. Education and Science, 39(176), 437-446.

[54] Zhang, I. \& Bartol, M. K. (2010). Linking empowering leadership and employee creativity: the influence of
Psychological empowerment, intrinsic motivation, and creative process engagement. The Academy of Management Journal, 53 (1), 107-128.

[55] Zimmerman, B. J. \& Martinez-Pons, M. (1990). Student differences in self-regulated learning: Relating grade, sex, and giftedness to self-efficacy and strategy use. Journal of Educational Psychology, 82, 51-59. 